DOI: https://doi.org/10.51209/platform.2.4.2021.189-204 УДК 7.791 .83

Людмила Олексіївна ШЕВЧЕНКО, Народна артистка України, Народна артистка СРСР, Київська муніципальна академія естрадного та циркового мистецтв,

Київ, Україна, e-mail: shevchenko@kmaecm.edu.ua, ORCID: 0000-0003-1161-5951

\title{
ДО ПИТАННЯ ПРО ТВОРЧУ ДИНАСТІЮ ШЕВЧЕНКІВ В ІСТОРЇ̈ ВІТЧИЗНЯНОГО ЦИРКУ
}

Анотація. Стаття має на меті актуалізувати питання значення творчих династій в історії українського циркового мистецтва, від етапу його існування у складі радянського цирку, найсильнішого у світі, до сьогоднішнього дня, коли пишеться літопис сучасного вітчизняного цирку. Підкреслюється слабка ступінь дослідженості цього феномену в українському науковому просторі, наводяться провідні джерела інформації, які допомагають висвітлити питання. Дано стислий екскурс в історію становлення українського цирку, головні вектори його роботи, причини надзвичайної популярності та великого попиту в радянський період, загально проаналізовано його «золоту добу», пов'язану з активною гастрольною діяльністю. Виокремлено феномен циркової родини як один 3 фундаментальних при формуванні характеру, специфіки циркового мистецтва, особливо в жанрі дресури при роботі 3 хижаками, де на першому місці стоять взаємодовіра та надійність партнерів, які мають роботу, пов'язану з постійним ризиком для життя. Акцентуються основні риси, що $\epsilon$ стилеутворюючими при народженні нових атракціонів, унікальних трюків. Підкреслено місце творчості циркового подружжя Шевченків в історії радянського та українського 
цирку, висвітлюються головні програми, унікальні трюки, що увійшли в історію світового цирку, зроблено акцент на ролі конкретних персоналій у творчих біографіях артистів подружжя Шевченків (Б. Едер). Описано історію виникнення окремих складних трюків центрального атракціону тандему дресирувальників («Дресировані левиці»), шлях від початку роботи з хижаками до всесвітньо відомого номеру, аналогів якому до цього часу немає в жодній країні світу. Окремо акцентовано різні вектори творчого шляху кожного 3 дресирувальників: акробатику у Л.Ш., роботу В.Ш. у кінематографі (його амплуа як актора режисера, каскадера), співробітництво 3 легендарними режисерами. Стаття має характер нарису з елементами мемуаристики, побудована на матеріалах спогадів, інтерв'ю, рецензій на відомі циркові атракціони, програми за участі творчого тандему В. та Л. Шевченків

Ключові слова: циркове мистецтво, творча династія, дресирувальник, атракціон, хижак, трюк

Вступ. Розквіт Радянського цирку припав на повоєнні роки. Він став можливим завдяки системному підходу до організації його роботи, професійній підготовці артистів, розвитку мережі стаціонарних цирків, організації діяльності циркового конвеєра. Одним із напрямків його розвитку було створення національних циркових колективів. Хоча, справедливості заради, треба сказати, що цей процес супроводжувався бурхливими творчими суперечками. Потрібно було, щоб на арені зазвучало українське слово, щоб заграли сила, спритність і відвага, лихі танці і музичність українців. Наївно було б припускати, що новий український цирк з'явиться чимось абсолютно відмінним від усього, що до цих пір демонструвалося на арені. Та й ніхто не ставив такого завдання. Але українські циркові артисти прагнули створити номери, які б i формою, i змістом відображали в якійсь мірі культуру українського народу. З'явився, наприклад, оригінальний номер «Гуцульські акробати», абсолютно не схожий на звичайний 
груповий акробатичний номер. У чисто жартівливому ключі вирішений номер жонглерів Філіпенків. Одну з комічних ролей грав К. Мусін, який увійшов у програму Українського цирку і значно збагатив ії. Гідними партнерами Мусіна виступали коміки В. Байда і П. Копит. Працювали гуцульські жонглериантиподисти Микитюки, буковинський наїзник Рогальський, танцівник на дроті Гвоздьов...

Постановка проблеми. У великих і цікавих творчих шуканнях народилася перша програма Українського цирку, названа «День народження». Прем'єра відбулася в Києві 23 липня 1956 р. До програми увійшли артисти різних жанрів: повітряні гімнасти Криленки, музичні ексцентрики і жонглери Філіпенки, пластичний етюд у виконанні Лисиненка, антиподисти Микитюки, «Музична кухня» артистів Алексєєнко, танцювально-акробатичний ансамбль «Гуцульські акробати» під керівництвом В. Максимова, повітряний апракціон «Мертва петля» Н. Сорокіної і П. Маяцкого, «Ведмежі забави» А. Подчернікова, акробати-вольтижери В. Фоменко, М. Таланкіна, С. Бєлов, кінно-спортивний номер Рогальського, музичні ексцентрики А. Аронов і В. Байда. У програмі були також номери, що представляють жанр клоунади: коверні клоуни К. Мусін, В. Байда і П. Копит, клоунада по назвою «Анонім» (артисти В. Байда, А. Зуб, П. Копит. С. Корячко), звучали гумор і сатира (артисти П. Водолага і Ф. Пригожий). Після успішного виступу колективу в Києві почалися його гастролі по країні.

У 1960 р. колектив успішно виступав в Москві, де в той час проходила Декада української культури й мистецтва. Були в програмі і нові виконавці, серед них: Ельвіра Косяченко, майбутня заслужена артистка України, кінно-спортивний номер «Запорізькі козаки». Великим успіхом користувався номер музичних ексцентриків Олени i Бориса Гріньє. Завершував виступ Українського циркового колективу в Москві атракціон Маяцького «Куля сміливості».

Склад колективу змінювався, доводилося ставати на репетиційний період. У пресі навіть з'являлися повідомлення, 
що колектив припинив свої виступи. Але після перерви гастролі незмінно поновлювалися. Київський цирк цілком прийняв на себе турботи про художньому і професійному стані колективу.

Аналіз останніх досліджень і публікацій. Історія вітчизняного цирку - царина i досі мало висвітлена. Існує чимало інтерв'ю, в тому числі - 3 автором даної статті (Л.Ш.), розпорошених публікацій у періодиці, в першу чергу - доволі давніх, 1960-80-х рр., тобто «золотої доби» радянського цирку. Було кілька дослідників, чиї праці заклали підвалини радянського циркознавства [1-4; 7], деякі з них немало писали і про український цирк, як К. Ганешин, перу якого належить багато очерків про цирковий світ, окремі програми, артистів, у тому числі - подружжя Шевченків [1-4]. Але в товстому шарі цієї інформації майже немає наукових розробок, перші спроби почали 3'являтися тільки останніми роками. Серед авторів теоретичних штудій зараз і самі артисти цирку, які є безцінним джерелом інформації для читачів. Багато в чому доводиться спиратися на крупиці інформації, систематизуючи їх, - спогади, інтерв'ю, буклети, програми виступів, то ж, не науковопопулярний жанр джерел.

Мета даного нарису - актуалізувати роль творчої династії Шевченків в українському цирковому просторі, що автор намагається зробити, спираючись на публікації журналістів та мистецтвознавців минулих років, багато в чому вибудовані на інтерв'ю, які давалися самим цирковим тандемом В. та Л. Шевченків.

Виклад основного матеріалу. Робота в «передвижках», гастролі, невлаштований побут диктують певні особливості життя циркових родин. Циркова сім'я має на увазі партнерство не тільки в житті, але й на арені. У кожного $є$ своє місце в цирковій ієрархії. Ніхто не залишається без справи. Часто циркова сім'я - це партнери за номером, один допомагає іншому в роботі, бере на себе якісь обов'язки в колективі. Ніхто не прийде ззовні і не зробить того, що буде потрібно в конкретний момент, - чи то догляд за тваринами, чи налагодження костюмів, продаж квитків, робота в уніформі, приготування їжі. 
Діти - не виняток. Народжених у циркових сім'ях, за традицією, називають «опілочниками». До слова, тирса вже йде в історію, витісняється сучасними покриттями, але подекуди ще використовуються, наприклад, у Монте-Карло, де кінні номери демонструються за всіма правилами циркових традицій - на тирсі.

«Опілочники» - діти особливі, завжди з батьками - на репетиціях, під час вистав, у гущі побутових проблем, а щойно тільки підростають - починають, у міру сил і кмітливості, допомагати. Знаючи дивовижний магнетизм цирку, не дивно, що більшість із «опілочників» іде по стопах батьків.

Історія циркової династії Шевченків почалася майже сто років тому. Засновник династії, Дмитро Терентійович Шевченко, був серед корифеїв радянського цирку. Його можна віднести до плеяди людей, які створювали, зберігали i передавали наступним поколінням циркові традиції.

Але сімейна історія Шевченків була неординарною. Першою дружиною Дмитра Терентійовича була рідна сестра матері Володимира Шевченка, Ніна, у них був син Валентин. Потім подружжя розлучилося, і Дмитро одружився зі старшою сестрою, що і стала матір'ю Володимира. Коли Олександра вийшла заміж за Шевченка, Ніна поїхала і від образи залишила Валентина сестрі та колишньому чоловікові. Володі тоді було років п'ять. Дмитро Терентійович став для нього справжнім батьком, дав хлопцю «путівку в життя».

Сім'я, дитячі роки автора цієї розвідки (Л.Ш.) зовсім не були схожі на дитинство Володимира Дмитровича. Ні про який цирк у роздумах про майбутнє мова не йшла, подібність доль була хіба що в тому, що характери обох гартувалися у важкі повоєнні роки. 3 малих років (Л.Ш.) хотіла бути лікарем. Дитинство фактично пройшло серед медиків, бо мама і бабуся все життя пропрацювали в психлікарні. Тому була одна мета медицина.

Дід (Л.Ш.) мав польсько-російське коріння, все життя прожив у Даугавпілсі, будував мости й дороги, був підрядником, у 75 років працював виконробом на будівництві. 
Батько був завжди при посадах, брат батька, Семенов, був Героєм Радянського Союзу, загинув під час війни. У двох тіток чоловіки були партійцями - військовими, полковниками, фронтовиками, потім один дядько став директором заводу, інший - адвокатом. Мати під час війни працювала у шпиталі, в Канаші, в Чувашії, куди привезли пораненого батька. Там батько і освічився мамі в коханні, коли його везли на операцію. Після одужання батька комісували з військової служби, і вони так і залишилися в Канаші. I донька (Л.Ш.) народилася в Чувашії, звідки дитину відвезли до Прибалтики, а вже звідти мати втекла з дитиною до Львова, де жили бабуся і тітка, мамина сестра. У тітки чоловік теж був військовим льотчиком. Так у два роки (Л.Ш.) опинилася у Львові. У школі почала займатися спортом, художньою гімнастикою. Тоді існувало спортивне товариство «Локомотив». І коли в школі відбирали 8річних дівчаток до секції, тренер, Любов Василівна Гальмо, колишня балерина, яка присвятила все своє життя дітям, знайшла (Л.Ш.), почалися зайняття. Вона викладала в інституті фізкультури, а в «Локомотиві» вела секцію. Потім був спортивний інтернат, але на іншому кінці міста, і на два роки тренер передала (Л.Ш.) в інше спортивне товариство. Інтернат вважався одним із кращих у Союзі.

Заняття спортом принесли свої плоди. У 17 років (Л.Ш.) зібралася і поїхала до батька в Даугавпілс, але в ньому не було ніяких можливостей займатися спортом, була лише одна секція спортивної гімнастики. Далі був вступ до московського циркового училища, несподіваний і випадковий за вибором. Навчання в училищі та життя в Москві захопили цілком, усе було нове, незвичайне, цікаве: спорт, громадська робота, все, до чого звикла за роки навчання в інтернаті та у школі, тут було ще яскравіше, цікавіше. Було чимало пропозицій і від гімнастів, i від акробатів, які шукали собі партнерок для номерів.

Компанії того часу були досить дисидентськими, дуже любили Висоцького. Серед знайомих згодом бути члени родини академіка Ландо, потім - Параджанов. 
Під Москвою, у Люберцях, під час виступів у шапіто (Л.Ш.) вперше побачила клітини 3 хижаками, поринула в закулісне життя пересування. Тоді ж вперше увійшла в клітку з чотирма левенятами-самочками. У 1966 р. Шевченки, вже будучи подружжям, подали сценарій-заявку на власний атракціон. Було створено маленьку циркову виставу, в якому поєднано повітряну гімнастику, акробатику i дресуру. Конкуренція тоді була величезна: 19 атракціонів із хижаками по країні. Потрібно було робити що-небудь нове. Так з 1967 р. 3'явився атракціон із дресированими левицями, що згодом став легендарним.

У 1967 р. Володимир і Людмила Шевченки отримали призначення в Український цирковий колектив. Київський цирк входив у число кращих радянських цирків. А самостійну роботу вони почали в 1968 р. в Уфі. Там не було стаціонарного цирку, тільки шапіто, перша i остання така спроба у тандему дресирувальників (за винятком однісї спроби в Болоньї).

Л.Ш. погодилася разом із чоловіком (В.Ш.) брати участь в атракціоні з левами. Це була не просто демонстрація трюків із тваринами, а справжня циркова вистава. До Шевченків ніхто нічого подібного не робив. (Л.Ш.) літала на трапеції над «килимом» із левиць, потім тримала кільце, через яке стрибали 200-кілограмові кішки. Людмила втілювала м'якість, ліричність, i під цей образ для підбиралися неї трюкові комбінації. Наприклад, погладити левицю або лягти їй на спину. Залишався ще один фактор - фактор хижого звіра. Коли актори тільки почали разом репетирувати 3 тваринами, чоловік дуже боявся першої травми актриси, не знав, як тендітна жінка на це відреагує. Від цього взагалі залежала вся подальша доля тандему. Але жінка повела себе досить мужньо - заштопана, відлежалася в лікарні, і робота продовжилася. Здібності артистів дозволили зробити вельми оригінальний атракціон: під час вистави показували й акробатичні номери, причому, тварини в них теж були задіяні. Спочатку було 5 левиць у програмі, потім - 12. Пізніше до левів додалися і тигри: 18 хижаків у клітці одночасно! 
У «Союзцирку» атракціонів із хижими тваринами було багато. Зазвичай артист отримував звірів, якщо зумів їх вибити, років біля 40. «Союздержцирк» був гігантською структурою, у країні було близько 60 цирків, усе це поділялося на певні сектори. У центральній працювали кращі, у Сибіру, на Уралі були слабші артисти, на Далекому Сході, у Середній Азії теж, далі за ієрархією йшли пересувні цирки, шапіто, теж трьох категорій. Прекрасні цирки були у крупних містах, особливо - у столичних: Ленінграді, Мінську, Києві, Москві, Пермі, Омську, в яких гастролювали і закордонні програми.

На той час було близько 20 «кліток»: ще працювали Борисов, Бугримова, Назарова, Рубан, Федотов, у яких були дуже відомі номери. Бугримова почала «робити клітку» Денисову, якому купили тигрів.

I Шевченки знову почали робити новий атракціон iз хижаками. В.Ш. набирав своїх тварин, у нього на другому курсі навчання вже були 3 своїх левиці.

У 1967 р подружжя працювало в Іжевську, у старому цирку. Самі робили реквізит, варили піраміди для атракціону. Всі левиці були дорослі - одній було 4 роки, найменші були «дворічки», малюків не брали, щоб не ростити. За півроку зробили практично весь атракціон. Завдання було придумувати трюки, щоб не бути схожими ні на кого. Припустимо, дресирувальниця лежить на левиці, а інша левиця стрибає через них, потім повітря, кільце - актриса у підтримці, а левиці стрибають у кільце. На початку актриса виходила в клітку в темряві, бралася за трапецію, піднімалася, в цей час дресирувальник випускав левиць, вибудовував, жінка у «п'ятах» опускалася, картинка висвічувалася «пушками». Навіть початок був незвичайний, актрису опускали, потім піднімали, вона сходила, звірі розбіглися, і починалася робота. Піраміда була в середині, актриса лізла на канат і спускалася на левів у шпагат. (В.Ш.) сконструював спеціальний велосипед, придумав прийоми, якими можна змусити звіра крутити педалі. I домігся, що левиця влаштовується на спеціальному сидінні, передні лапи кладе на кермо, задні ставить на педалі, натискає на них, i 
велосипед зі звіром рухається по манежу. I ще була підкидна дошка в клітці з левами. Зазвичай за допомогою такої дошки акробати роблять різні стрибки. Два виконавці стрибають на дошку $з$ тумби, а їх партнер злітає і демонструє сальто або пірует. У Шевченка цей акробатичний трюк проробляють людина і звір. Левиця по команді стрибає з тумби на піднятий кінець дошки i підкидає дресирувальника, який виконує в польоті сальто.

У програмі виступу був унікальний момент - танець дресирувальника та левиці. (В.Ш.) танцює з нею танго: піднімає левицю на задні лапи і дає їй покласти передні собі на плечі. I ось уже звучить знайома всім мелодія. Під неї і рухається по манежу танцююча пара. Потім (Л.Ш.) робить вправи на кор-депарель - вертикальному канаті. Коли артистка спускається вниз, три левиці підставляють їй свої спини, і вона виконує на цій живій опорі шпагат. А завершивши трюк, актриса боком сідає на одного зі звірів - секунду перепочити. Були і складніші трюки: Володимир рухається по буму вниз головою, чіпляючись носками за петлі (трюк «муха»). Над ним по колоді по дерев'яних пляшках обережно ступає левиця. Рухи людини i хижака синхронні. У таких незвичайних трюках дресирувальник i звір виступають на рівних, тут немає командувача i виконуючого накази. А якщо виникають конфлікти, то вирішуються вони не силою, не загрозою покарання.

Знавці цирку можуть нагадати, що за кордоном і зараз у клітках із хижаками виступали танцівниці, а над клітками повітряні гімнастки. Але в цих випадках танцівниць і гімнасток ніяк не назвеш партнерами звірів. Найчастіше ці виступи подаються так: немов беззахисна дівчина серед лютих тигрів, гімнастка виконує ризиковані трюки, якщо зірветься - їй буде непереливки...

В атракціоні Шевченків зовсім інше. Коли витончена Людмила проробляє вправу на вертикальному канаті, левиці беруть участь в ії трюку. Артистка стрімко зісковзує вниз, і три левиці підставляють їй свої руді спини; вона виконує на них шпагат. Володимир у красивому стрибку зустрічається в повітрі 
3 левицею - так би мовити, перехресний політ звіра й людини. До речі, і раніше шукали нові риси взаємовідносин людини і звіра. В одному випадку тигра кокетливо гладили - і виявилося, 3 ним можна обходитися, як $з$ великою кішкою. В іншому дресирувальниця забиралася 3 левом на маленький майданчик гойдалки, і звір ставав ніби учасником розваг людини. I з'ясувалося, що до царя звірів можна ставитися мало не зі зневагою, носити його на плечах, як горжетку.

Але не робили хижака співучасником трюків. Цим шляхом i пішли Шевченки. Новий характер стосунків дресирувальників і звірів вони знайшли в злитті жанрів дресури 3 акробатикою та гімнастикою. Зараз майстри манежу в пошуках нового часто об'єднують жанри. Можна бачити, наприклад, номер жонглера, в якому основний трюк - еквілібрування, або акробатів, які перенесли свої виступи під купол. Об'єднання жанрів зазвичай надає номеру свіжість, оригінальність. Це ми бачимо і у Шевченків.

Новий атракціон Шевченків курирував Борис Опанасович Едер, дресирувальник зі світовим ім'ям, що дав дуже багато цінних порад.

То була робота двох акторів - просто ходити в клітці вони не могли, бо глядачеві це не цікаво. А Едер, який приймав новий атракціон, бачив набагато більше, ніж звичайний глядач. Він знав ціну трюку i легкості руху в манежі, i, напевно, відчував потенціал молодого тандему. Під його поглядом i відбувся новий дует дресирувальників і новий атракціон. Це була унікальна людина, великий дресирувальник. Усі атракціони $з$ хижаками, з ведмедями, з птахами, все, що було в Радянському Союзі, починалося 3 нього. Коли в «Держцирку» Дуров кинув клич прибрати з арени всіх іноземців і запустити радянських акторів, з'явилися Гладильщиков, Рубан. Борису Опанасовичу доручили прийняти у Карла Зембаха атракціон 3 левами (держава викупила хижаків і відступати було нікуди), а він до цього в клітку жодного разу в житті не входив. Через місяць Едер уже виступав із левами самостійно. Борис Опанасович брав тварин (леопардів, тигрів, пум, левів, 
ведмедів), робив номери й віддавав їх. Серед його вихованців було чимало прославлених дресирувальників - Федотов, Іванов з ведмедями-канатаходцямі, Вальтер Запашний. Він був дійсно унікальним дресирувальником, працював навіть із птахами. Звірів добре знав, відчував. Останній раз Шевченки 3 ним зустрілися в 1969 р. на гастролях.

Клітка стала для подружжя не тільки місцем роботи. Вона задавала тон в житті, вчила й виховувала. Піклуватися один про одного і прикривати в складних ситуаціях - це норма для людей, які щодня ризикують життям. Професіонали завжди чітко знають - щонайменша помилка одного може коштувати іншому життя. Актори довіряли один одному, і ця довіра була багато разів випробувана в житті. В.Ш. намагався все небезпечне робити сам, прикривав дружину собою від звірів, не підпускав до них. Взагалі, у нього було сильно розвинене почуття відповідальності за оточуючих його людей. У клітці спочатку він не давав дружині працювати з тваринами, оберігав. Але вона при кожному зручному випадку брала ініціативу в свої руки.

В.Ш. за межами манежу був досить обережною людиною, але щоб якось вирішувати матеріальні проблеми, знайшов досить екстремальний спосіб заробляти, який теж був пов'язаний із ризиком для життя: на «Мосфільмі» працював каскадером - знімався в трюках та епізодах стрічок «Гіперболоїд інженера Гаріна», «Війна і мир», ін.

Людина в клітці 3 хижаками завжди оточена ореолом романтики. Юнаки, дівчата іноді спалахують бажанням вийти на яскраво освітлений манеж, оточений сталевими гратами, i безстрашно керувати левами або тиграми. I вони задають питання: а як стати дресирувальником хижаків? Відповідь одна: треба стати артистом, а потім пробувати свої сили в дресурі [2].

Напружена творча робота молодих дресирувальників, новаторський підхід, незвичайні трюки - все це викликало жвавий інтерес глядачів. Такого вони точно ніколи раніше не бачили. [2]. 
Висновки. У 1980 р. Володимир Шевченко почав формувати новий, молодіжний склад Українського колективу. Цей колектив став кращим національним колективом у «Союздержцирк». В афіші з'явилися нові імена, на кшталт еквілібристів під керівництвом заслуженого артиста України Анатолія Стеценка, чий номер називався «Літаючі Перші». Виступали в складі українського циркового колективу гімнасти i на т. зв. потрійному турніку з десятьма перекладинами. Керував групою гімнастів заслужений артист України Ігор Бессараб. На потрійному турніку артисти виконували не лише складні сольні трюки, а й групові, коли чотири, шість або сім чоловік одночасно, часто синхронно або в суворо визначеній послідовності, перелітали 3 поперечини на поперечину, міняючись місцями i створюючи складний композиційний малюнок польоту.

У підготовці та оновленні програм українського колективу брали участь директор i художній керівник Київського цирку, народний артист Української РСР Борис Заєць, балетмейстер i режисер, заслужений діяч мистецтв Української РСР Олександр Зайцев, талановиті літератори, художники і композитори. Виступи колективу проходили в багатьох містах Білорусії, Грузії, Вірменії, Латвії, Росії, Узбекистану. Український колектив припинив своє існування після розвалу Радянського Союзу, в 1996 р.

I почалася сторінка самостійного сегменту історії циркового мистецтва, в якій феномен «Шевченко», як і раніше, посідає одне з провідних місць.

\section{Список використаної літератури:}

1. Ганешин К. Цена легкости. Советская эстрада и цирк. 1974. № 4.

2. Ганешин К. В перекрестном прыжке. Советская эстрада и цирк. 1968. № 12.

3. Ганешин К. Трудные и радостные будни. Советская эстрада и цирк, 1983. № 10 (313). Сс. 25-27. 
4. Ганешин К. Режиссёр нужен всем. Советская эстрада и цирк. 1968. №1.

5. Дмитриев Ю. Советский цирк сегодня: очерки. Искусство, 1968. Сс. 65-72.

6. Маяцкий П. Прошло два года. Советский цирк. 1958. № 6 .

7. Рыбаков М. Киевский цирк: люди, события, судьбы. Киев: Атика, 2006. 304 с.

8. Шевченко Л. Дресура тварин: зародження явища, стадії еволюції та актуальні проблеми сьогодення. Арт-платформа. 2021. Вип. 1(3). Сс. 107-122.

9. Шнеер А., Славский Р. Украинский цирковой коллектив. Цирк. Маленькая энциклопедия. Москва: Советская энциклопедия, 1979. 337 с.

\title{
Людмила Алексеевна ШЕВЧЕНКО, \\ Народная артистка Украины, \\ Народная артистка СССР, \\ Киевская муниципальная академия \\ эстрадного и циркового искусств, \\ Киев, Украина, \\ e-mail: shevchenko@kmaecm.edu.ua, \\ ORCID: 0000-0003-1161-5951
}

\section{К ВОПРОСУ О ТВОРЧЕСКОЙ ДИНАСТИИ ШЕВЧЕНКО В ИСТОРИИ ОТЕЧЕСТВЕННОГО ЦИРКА}

\begin{abstract}
Аннотация. Статья имеет целью актуализировать вопрос значения творческих династий в истории украинского циркового искусства, от этапа его существования в составе советского цирка, сильнейшего в мире, до сегодняшнего дня, когда пишется летопись современного отечественного цирка. Подчеркивается слабая степень изученности этого феномена в украинском научном пространстве, приводятся ведущие источники информации, которые помогают осветить вопрос. Даны краткий экскурс в историю становления украинского


цирка, главные векторы его работы, причины чрезвычайной популярности и большого спроса в советский период, в общем проанализирован его «золотой век», связанный с активной гастрольной деятельностью. Выделен феномен цирковой семьи как один из фундаментальных при формировании характера, специфики циркового искусства, особенно в жанре дрессуры при работе с хищниками, где на первом месте стоят взаимное доверие и надежность партнеров, имеющих работу, связанную с постоянным риском для жизни. Подчеркнуто место творчества цирковой супружеской пары Шевченко в истории советского и украинского цирка, освещаются главные программы, уникальные трюки, вошедшие в историю мирового цирка, сделан акцент на роли конкретных персоналий в творческих биографиях артистов, супругов Шевченко (Б. Эдер). Описана история возникновения отдельных сложных трюков центрального аттракциона тандема дрессировщиков («Дрессированные львицы»), путь от начала работы с хищниками к всемирно известному номеру, аналогов которому до сих пор нет ни в одной стране мира. Отдельно акцентированы разные векторы творческого пути каждого из дрессировщиков: акробатика у Л.Ш., работа В.Ш. в кинематографе (его амплуа как актера, режиссера, каскадера), сотрудничество с легендарными режиссерами. Статья носит характер очерка с элементами мемуаристики, построена на материалах воспоминаний, интервью, рецензий на известные цирковые аракционы, программы с участием творческого тандема В. и Л. Шевченко

Ключевые слова: цирковое искусство, творческая династия, дрессировщик, аттракцион, хищник, трюк 


\title{
LYUDMYLA O. SHEVCHENKO, \\ National Artist of Ukraine, National Artist of USSR, Kyiv Municipal Academy of Circus and Performing Arts, \\ Kyiv, Ukraine, e-mail: shevchenko@kmaecm.edu.ua, ORCID: 0000-0003-1161-5951
}

\section{ON THE QUESTION OF THE CREATIVE DYNASTY OF SHEVCHENKO IN THE HISTORY OF THE DOMESTIC CIRCUS}

\begin{abstract}
The article aims to actualize the issue of the importance of creative dynasties in the history of Ukrainian circus art, from the stage of its existence as part of the Soviet circus, the strongest in the world, to the present day, when the chronicle of the modern national circus is being written. The low degree of knowledge of this phenomenon in the Ukrainian scientific space is emphasized, leading sources of information are given that help to highlight the issue. A brief excursion into the history of the formation of the Ukrainian circus, the main vectors of its work, the reasons for the extreme popularity and great demand in the Soviet period are given, in general, its "golden age" associated with active touring activities is analyzed. The phenomenon of the circus family is highlighted as one of the fundamental in the formation of the character, the specifics of circus art, especially in the genre of training when working with predators, where in the first place is the mutual trust and reliability of partners who have a job associated with a risk to life. The place of creativity of the Shevchenko circus couple in the history of the Soviet and Ukrainian circus is emphasized, the main programs, unique tricks that have entered the history of the world circus are highlighted, an emphasis is placed on the role of specific personalities in the creative biographies of the artists, the Shevchenko spouses (B. Eder). The history of the emergence of individual complex tricks of the central attraction of the tandem of animal trainers ("Trained lionesses") is described, the path from the beginning of work with predators to the world-famous
\end{abstract}


number, which has no analogues in any country in the world. Separately, the different vectors of the creative path of each of the trainers are emphasized: acrobatics by L. Sh., The work of V. Sh. in cinema (his role as an actor, director, stuntman), collaboration with legendary directors. The article is in the nature of an essay with elements of memoirism, based on materials from memoirs, interviews, reviews of famous circus aractions, programs with the participation of the creative tandem of V. and L. Shevchenko

Key words: circus art, creative dynasty, trainer, attraction, predator, trick

\section{Refereces:}

1. Ganeshin, K. (1974). Tsena legkosti [The price of lightness]. Sovetskaya estrada i tsirk, 4 [in Russian]

2. Ganeshin, K. (1968). V perekrestnom pryzhke [In the cross jump]. Sovetskaya estrada i tsirk, 12 [in Russian]

3. Ganeshin, K. (1983). Trudnyye i radostnyye budni [Difficult and joyful everyday life]. Sovetskaya estrada i tsirk, 10 (313), 25-27 [in Russian]

4. Ganeshin, K. (1968). Rezhissor nuzhen vsem [Everybody needs a director]. Sovetskaya estrada i tsirk, 1 [in Russian]

5. Dmitriyev, Yu (1968). Sovetskiy tsirk segodnya: ocherki [Soviet circus today: essays]. Iskusstvo, 65-72 [in Russian]

6. Mayatsky, P. (1958). Proshlo dva goda [Two years have passed]. Sovetskiy tsirk, 6 [in Russian]

7. Rybakov, M. (2006). Kievskiy tsirk: lyudi, sobytiya, sud'by. Kiev: Atika [in Russian]

8. Shevchenko, L. (2021). Dresura tvaryn: zarodzhennya yavyshcha, stadiyi evolyutsiyi ta aktual'ni problemy s'ohodennya [Animal training: the origin of the phenomenon, stages of evolution and nowadays]. Art-platforma, 1(3),107-122 [in Ukrainian] 9. Shneyer, A. \& Slavskiy, R. (1979). Ukrainskiy tsirkovoy kollektiv [Ukrainian circus collective]. Tsirk. Malen'kaya entsiklopediya. Moscow: Sovetskaya entsiklopediya [in Russian] 